\title{
$\beta$-サイクロデキストリンの生産とその利用
}

\author{
掘越 弘 毅, 中 村 信 之* \\ 理化学研究所
}

サイクロデキストリンは別名シャールディンガーデキ ストリン (Schardinger dextrin) とも呼ばれる環状同 族オリゴ糖であり, サイクロデキストリングリコシルト ランスフェラーゼ (cyclodextrin glycosyltransferase; CGTase) または別名マセランスアミラーゼ (macerans amylase）と呼ばれる酵素によって澱粉から作られる. サイクロデキストリン自体の発見は非常に古く，1891年 にさかのぼることができる(1)が, Schardinger(2) が CGTase を作る バクテリアを Bacillus macerans と同定 し，またサイクロデキストリン（以下 CD と略す）の製 造，性質について詳細に報告したため， Schardinger dextrin と呼ばれるようになった. その後, この変わっ た構造の化合物は他の多糖類と非常に違った性質をるっ ているため, 糖の研究者の多くをひきつけた. CD の二 ニークな性質とは次のようなるのである(3 5).

a) CD $\alpha 1: 4$ 結合をしたグルコース単位を6つ かまたはそれ以上をるつ均一な環状化合物である。

b）この化合物は環状であるため，還元末端，非還元 末端のいずれをももたない.

c）酸に対して比較的抵抗性で, 普通のアミラーゼに よっても分解されにくい.

d） 7 つのグルコースよりなる $\beta-C D$ は非常に結晶し やすい性質をもっている.

e ）多くの有機溶媒を CD の空洞内にとり込み，包接 化合物を作る.

f）無機物，たとえばハロゲンなどとも包接化合物を 作る.

\footnotetext{
* 現在日本食品化工株式会社
}

実際にこのような変わった性質をもつ化合物を工業 的スケールで作り, 利用しよらといら試みはいくつかの 会社で行なわれた. 1968 年, 米国の CP International 社は B. macerans の CGTase を用いて $\beta-C D$ を作り， その用途開発を試みた(8). 次いで, 日本の帝人株式会社 がパイロットプラントスケールで製品を作ったが，その 製法にいくつかの問題があったため成功しなかった(7). しかし, この両者の研究が $\beta-C D$ の用途増大に役立った ことは明らかである.

では,この問題とはどのようなものであったか. 列記 すると，a）B.macerans の CGTase は製造が困難で あるら光, 熱耐性もあまりよくないため, 大量生産には 向いていない，b）澱粉からの収率があまりよくないた め, 収率を向上させる目的で有機溶媒を用いることが必 要である，c）この際に用いる有機溶媒はトリクロロエ チレン,ブロモベンゼンなどのように有毒なものが多い, などである. 特に c) の問題は重大であって, $\mathrm{CD}$ の製 造コストを増大させるだけではなく，このようにして作 られた CD は食品などに用いることができない，したが って，大量使用への道がふさがれていたことになる。

1969年，筆者らは好アルカリ性細菌を用いたアルカリ 性醱酵法を開発し，同法によって作りだされるいろいろ な酵素の研究を行なってきた ${ }^{(8)}$. その際に, Bacillus No. 38-2 菌の作りだす CGTase が，澱粉を優先的にし かも非常に高収率で $\beta-C D$ に変換することを見いだし た ${ }^{(9 \sim 13)}$.この CGTase を用いて，有機溶媒をまったく 用いないで $\beta-C D$ を業的スケールで生産することが可 能となった. 厚生省はこれを化学的合成品ではないと認 
めたため, 食品への利用も可能となり， $\beta-C D$ の大量利 用への道が開けた、本稿では, 筆者らが開発した $\mathrm{CD}$ の 製造法とその利用について述べることにする.

\section{新しいCGTase の分離とその性質}

約 600 株の好アルカリ性菌のうちから $1 \% \mathrm{Na}_{2} \mathrm{CO}_{3}$ を 含む培地中に多量の CGTase を作り出す Bacillus No. 38-2 菌を分離した（詳細は文献(8)を参照されたい)．培

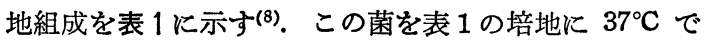
好気的に生育させ, 約 3 日間の培養後, 除菌, アセトン 沈澱をへて酵素粉末を作る. CGTase とよる CD 生産の ための $\mathrm{pH}$-活性曲線を図 1 と示した. $\mathrm{pH} 4.5$ から $\mathrm{pH} 9$ の間で実用上問題のない収率で $\beta-C D$ が作られることが 判る. また，この酵素は $\mathrm{Ca}^{2+}$ によって安定化され，約 $70^{\circ} \mathrm{C}$ までその活性を保持した. 比較のためいくつかの CGTase の性質を表 2 に示す(14).

表 1 Bacillus No. 38-2 菌のためのアルカリ性培地

\begin{tabular}{lrlr}
\hline 可溶性デソプソ & $2 \%$ & $\mathrm{~K}_{2} \mathrm{HPO}_{4}$ & $0.1 \%$ \\
ポリペプトン & $0.5 \%$ & $\mathrm{MgSO}_{4} \cdot 7 \mathrm{H}_{2} \mathrm{O}$ & $0.02 \%$ \\
イーストエキス & $0.5 \%$ & $\mathrm{Na}_{2} \mathrm{CO}_{3}{ }^{*}$ & $1 \%$ \\
\hline
\end{tabular}

* 別殺菌後加觉る.

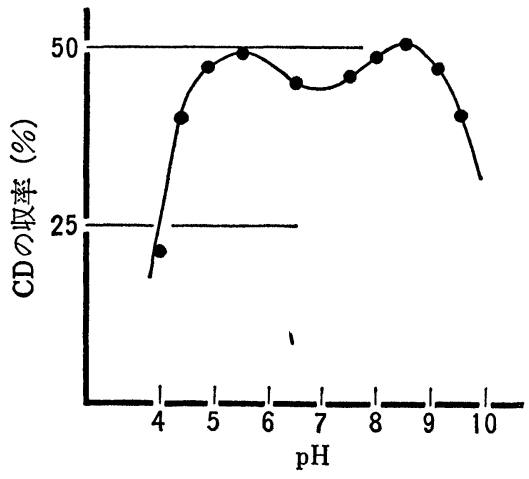

図 $1 \mathrm{CD}$ 合成収率の $\mathrm{pH}$ 依存性

表 2 各種 CGTase の性質(13)

\begin{tabular}{|c|c|c|c|c|c|}
\hline \multirow[b]{2}{*}{ Bacillus macerans } & \multirow{2}{*}{$\frac{\text { 最適 } \mathrm{pH}}{5.0 \sim 5.7}$} & \multirow{2}{*}{$\frac{\text { 安定 } \mathrm{pH}}{8.0 \sim 10.0}$} & \multicolumn{2}{|c|}{$\begin{array}{c}\text { 熱安定性 } \\
\left({ }^{\circ} \mathrm{C}\right) \\
\mathrm{Ca}^{2+} \\
(+)(-)\end{array}$} & \multirow{2}{*}{ 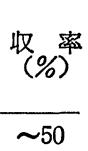 } \\
\hline & & & 50 & - & \\
\hline Klebsiella pneumoniae & 5.2 & 一 & - & - & 一 \\
\hline $\begin{array}{l}\text { Bacillus } \\
\text { stearothermophilus }\end{array}$ & $5.0 \sim 5.5$ & $5.5 \sim 8.8$ & 70 & 65 & 50 \\
\hline Bacillus megaterium & $5.0 \sim 5.7$ & $7.0 \sim 10.0$ & - & 55 & 62 \\
\hline Bacillus circulans & $5.2 \sim 6.1$ & $7.5 \sim 9.0$ & - & 50 & 一 \\
\hline Bacillus No. 38-2 & $4.5 \sim 9.0$ & $6.0 \sim 10.0$ & 70 & 60 & $75 \sim 8 \mathrm{c}$ \\
\hline
\end{tabular}

サイクロデキストリンの製造

筆者らが今まで行なってきた実験にはすべてバレイシ ヨ澱粉を用いたが，脱脂したコーンスターチなども利用 できる、アミロースを用いると，少しではあるが収量は 増大するが，コスト面からの有意差は見られない程度で ある. Bacillus No. 38-2 菌の酵素は，澱粉濃度 1\% の 仕込みの場合，実に 70 80\% 以上の収率で測粉を $\mathrm{CD}$ に変換する.このような高い収率は濒粉の枝分かれ構造 を考えると一見不可能のように思われるが，その機構に ついてはまだ明らかにされていない，理論的にみた場合， 基質濃度が低いほど収率は高くなる。このことは，実験 的にもたしかめられた。一方，工業的スケールで考えた 場合, 反応時の基質濃度が高い活ど処理量が増大し, 経 済的にも良いことは明らかである.このほか，いくつか の条件を考兄て，筆者らは仕込み濃度を $15 \%$ に決定し

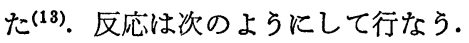

$10 \mathrm{mM}$ の $\mathrm{CaCl}_{2}$ を含む1トンのバレイショ䬺粉（15 \% w/v)を糊化した後, Bacillus No. 38-2 菌の CGTase で $\mathrm{pH} 8.5 ， 85 \sim 90^{\circ} \mathrm{C}$ の条件下で液化する．従来法では 糊化した後の液化を細菌アミラーゼを用いて行なってい たが，還元糖が増大するため，収率が著しく低下してい た. 上述の CGTase は還元糖をほとんど增加させない で粘度を低下させる性質をるっている，液化した後， $\mathrm{Ca}(\mathrm{OH})_{2}$ で $\mathrm{pH}$ を 8 8.5 に再調節し，さらにCGTase

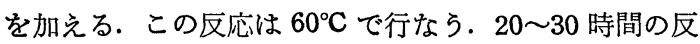
応後，100 120 ${ }^{\circ} \mathrm{C}$ に温度を上昇させて酵素を失活させ， $\mathrm{pH}$ を.5〜5.7 亿調節し，適当量のバクテリアの $\alpha-ア$
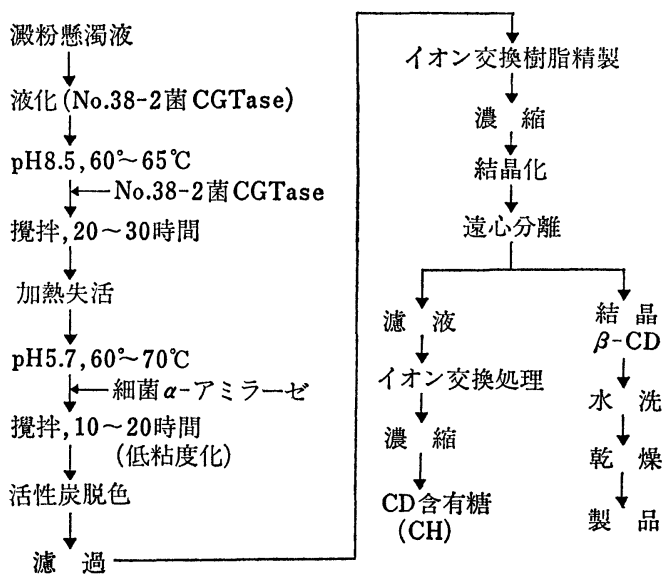

図 $2 \beta$-CD の製造法 
ミラーゼを加えて CD に变わらなかった搌粉の分解物を 加水分解する. これに活性炭を加えて脱色し，さらにイ オン交換樹脂による脱塩, 活性炭脱色をくりかえして無 色の反応液を得る。この液を減圧下で約 $60 \%(\mathrm{w} / \mathrm{v})$ 糖 質になるように濃縮し，少量の母結晶の $\beta-C D$ を加え， 徐々に温度を下げて $\beta-C D$ を結晶化させる，粗結晶を遠 心分離器で集め, 冷流水で洗浄し, さらに必要な場合は 定法通り熱水で再結を行なう，以上の操作を図 2 とまと めた。結晶を除去した濾液には $\alpha-C D, \beta-C D, \gamma-C D$ 特よ び糖質が含まれて怙り，その全 $\mathrm{CD}$ 含量が約 $20 \%$ であ るため，充分な包接能力をるっている．この“滤液”の 性質については次に述べる。

\section{$\beta$-CD と“濾液” の性質}

$\mathrm{CD}$ は, 現在 1 つのタイプの結晶品と 2 つのタイプの “滤液”製品が商品として販売されている. それらの規 格を表 3 に示した ${ }^{(15)}$. 最近は，この “滤液”を粉末にし た製品る開発されている.タイプ A と呼ばれている粉末 は，50\%の の CD を含む糖の混合物であるが，吸湿性が 低い(図 3)， $\beta$-CD は表 4 亿示すように，水に対する溶 解度はあまり高くはないが，濾液 $(\mathrm{CH})$ やタイプAは溶 解度が非常に高い(表 5 )。

表 3 CD 製品の規格

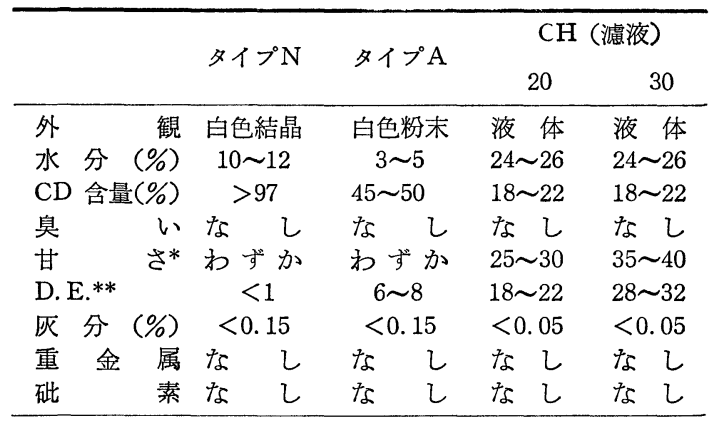

* $25^{\circ} \mathrm{C}$ の砂糖を 100 とした

** デキストロース等量

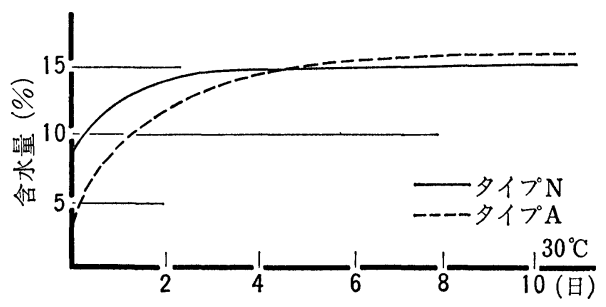

図 3 CD の吸湿性 ${ }^{(15)}$
表 4 各種 CD の性質

\begin{tabular}{lccc}
\hline & $\alpha-\mathrm{CD}$ & $\beta-\mathrm{CD}$ & $\gamma-\mathrm{CD}$ \\
\hline グルコース数 & 6 & 7 & 8 \\
分 子 量 & 973 & 1135 & 1297 \\
空洞の直径 $(\AA)$ & $5 \sim 6$ & $7 \sim 8$ & $9 \sim 10$ \\
空洞の深さ $(\dot{A})$ & $7 \sim 8$ & $7 \sim 8$ & $7 \sim 8$ \\
結晶形 $($ 水より) & 針状 & プリズム & プリズム \\
{$[\alpha]_{\mathrm{D}}^{25}\left(\mathrm{H}_{2} \mathrm{O}\right)$} & $+150.5^{\circ}$ & $+162.5^{\circ}$ & $+177.4^{\circ}$ \\
溶解度 $(\mathrm{g} / 100 \mathrm{ml}$, & 14.5 & 1.85 & 23.2 \\
水 $\left.25^{\circ} \mathrm{C}\right)$ & & & \\
\hline
\end{tabular}

表 5 各種 CD 製品の溶解度

\begin{tabular}{|c|c|c|c|c|}
\hline \multirow{2}{*}{ 温 } & \multirow{2}{*}{ 度 $\left({ }^{\circ} \mathrm{C}\right)$} & \multicolumn{3}{|c|}{ 溶 解 度 $(\mathrm{g} / 100 \mathrm{ml})$} \\
\hline & & タイプN & タイプA & $\mathrm{CH}$ (濾液) \\
\hline & 20 & 1.8 & 35 & 自由に水に溶 \\
\hline & 40 & 3.7 & 50 & ける \\
\hline & 60 & 8.0 & 55 & \\
\hline & 80 & 18.3 & 60 & \\
\hline & 100 & 256 & - & \\
\hline
\end{tabular}

\section{CD の安 全 性(16 18)}

Spraue-Dawely 種のアルビノラットを用いた CD の 安全性の実験例を表 6 亿示す，澱粉から酵素を用いて作 ったものであるので，毒性はないと想像されたが，この 実験はこのことを裏づけている. また，ビーグル犬を 用いた実験でもその安全性はたしかめられている。この ほか, いくつかの薬を包接させた場合の毒性試験でも, CD そのものはまったく無毒であることが明らかにされ ている. 一方，放射性 CD と激粉を用いた代謝の比較は まだあまり報告されていないが，体内にとり入れられた 場合，CD の分解の初速度はやや遅いが，24時間後はま ったく同じであり，同時に体内の分布も澱粉と同じであ ることが報告されている。

表 $6 \beta \boldsymbol{\beta}$-CD の安全性 ${ }^{(16,17)}$

\begin{tabular}{ccc}
\hline & 投 与 方 法 & $\mathrm{LD}_{50}(\mathrm{~g} / \mathrm{kg})$ \\
\hline \multirow{4}{*}{ 急性 毒性 } & 経 口 投 与 & $18.1 \pm 1.0$ \\
& 股 与 & $3.7 \pm 0.2$ \\
& 腹 腔 投与 & $0.7 \pm 0.1$ \\
\hline
\end{tabular}

慢性毒性 6 力月間, $0.1 \mathrm{~g}, 0.4 \mathrm{~g}, 1.6 \mathrm{~g} / \mathrm{kg}$ の割合で 連続的㳗口投与しても何らの変化も認めら れなかった。

\section{酵素および微生物による $\beta-\mathrm{CD}$ の分解}

$\beta-C D$ は普通の直鎖のデキストリンと比較して普通の $\alpha$ ーアミラーゼによって分解されにくい，また，末端が ないため，そこから分解していくタイプの酵素，たとえ 
ばグルコアミラーゼなどでは分解されない。さらに，枯 草菌の液化型アミラーゼ, ヒトの棰液アミラーゼなども 作用しにくい(14)。一方，上く分解するものとしては, 睝菌 アミラーゼ, Pseudomonas のアミラーゼ, B. macerans の CGTase, Bacillus No. 38-2 菌の CGTase などがあ る.

$\beta-C D$ を利用する微生物についてはまだ系統的には研 究されていないが, B. macerans, B.polymixa, Bacillus No.38-2，それに Klebsiella のある種などが報告され ている. このほかにも多くの微生物が分解, 利用するよ らである。一方，利用しないか，または利用しにくいも のとしては, Escherichia, Aerobacter, Klebsiella, Eberthella, Salmonella, Shigella, Saccharomyces などが報告されている(6).

以上, $\mathrm{CD}$ の製造法, 性質扣よび安全性について触れ てきたが，次に $\beta-C D$ 打よび $\beta-C D$ と糖との混合物の 利用，特に包接化合物としての利用について若干述べた い.

\section{包接化合物の作り方}

1） 水溶性化合物の場合(19)

$\mathrm{CD}$ の水溶液に, 包接させようとする物質の水溶液を 加え，沈澱が生ずるまで放置する．生じた沈澱を濾過し， 冷水で洗浄したのちアセトンまたはエーテルで洗い, 減 压下で乾燥する，沈澱を生じない場合は，凍結乾燥法に よって包接化合物を得ることもできる.

2）水に不溶な液状化合物の場合 ${ }^{(19)}$

CD の水溶液に目的物を加え，沈澱物が生ずるまで充 分振镯する.生じた沈澱は前述の方法で集める.

3）水に不溶な固体の場合 ${ }^{(19)}$

包接させようとする化合物をエーテルに溶かし，CD の水溶液に加える. 沈澱が生ずるまで充分振盪し, 前述 の方法と同じょうにして包接物を分離する.

\section{4）工業スケールでの包接化合物の作り方(7)}

混練法といわれる方法で, $\beta-C D$ の溶解度が低いこと を利用して和り，この方法が工業的スケールでは用いら れている. CD のスラリー (CD 1 に対して水 1〜5 倍 容を加光たもの) に目的とする化合物を加え（等モルま たはやや多めに)，ミキサーまたは擂潰機などを用いて充 分に混和する。一般に，時間とともに粘度が上昇し，ペ
ースト状となる. 通常 2〜5 時間の挸拌で充分である. 以後の包接化合物の処理は前述の通りである.

\section{包接化合物からのゲスト*化合物の分離}

\section{1）加 熱}

たいていの包接化合物は, 水の存在下で沸点またはそ の付近まで加熱するとダスト化合物と CD とに分かれる. また，一度分離したものも冷却することによって再び包 接化合物を形成する. 揮発性物質がゲスト化合物の場合 は，水蒸気蒸留で容易に分離することができる.

2) 抽出

適当な溶媒, たとえば熱メタノールなどでゲスト化合 物を抽出することができる場合がある。また，液体ク口 マトグラフィーのサンプルの場合などはジメチルスルフ オキサイドなどに溶かして用いることができる.

3）酸分解

ゲスト化合物が酸で分解されない場合は, 酸で CDを 分解することによって包接化合物を分離することができ る.

4）酵素分解

CD を酵素によって分解させ, 包接化合物を遊離させ ることができる.

\section{CD および CD 含有製品の用途}

研究対象, および一部の実用例では溶解度の高い $\alpha-$ $\mathrm{CD}$ が用いられているが，実用例のほとんどは，製造， 分離, 精製が容易で包接力の大きい $\beta-C D$ が用いられて いる. また, 筆者らが開発した $\mathrm{CD}$ を含む糖の混合物 $\mathrm{CH}$ もCD を含んでいるため，以下に述べる用途に用いられ ることはいらまでもない.しかし，いずれにしても市販 を始めてまだ 1 年余りのため，その多くは開発中または 特許出願中のものが多く，ここでそれぞれを説明するこ とはできないしまたそのスペースもない，一覧表とし て表 7 に示しておく.

$\mathrm{CD}$ の用途はその性質上から大きく分けて次の 5 つに 分類することができる.

1）揮発性物質の不揮発安定化作用がある.

a）有毒な揮発性物を包接・粉体化して保存性, 安 全性を増大させる.

* 包接分子をホスト，それにとり込まれる基質分子をゲス トという. 
表 $7 \mathrm{CD}$ および CD 含有製品の用途(7)

\begin{tabular}{|c|c|}
\hline 途 & ゲスト化合物または最終製品 \\
\hline \multicolumn{2}{|l|}{ 食 品 } \\
\hline 1) 乳 & $\begin{array}{l}\text { マヨネーズ,シーズニングオイル, } \\
\text { ホイッピソグクリームなど }\end{array}$ \\
\hline 2）起泡力增加 & $\begin{array}{l}\text { 卵白(22),ホットケーキミックス, } \\
\text { ケーキックスなぞ }\end{array}$ \\
\hline 3）フレーバの安定化 & $\begin{array}{l}\text { チニーインジガム, ビスケット， } \\
\text { シニズニングパウダーなど }\end{array}$ \\
\hline 4）味のマスキング & ミートペースト \\
\hline \multicolumn{2}{|l|}{ 化粧品(トイレタリー) } \\
\hline 1) 色のマスキング & 螢光物質了溶剂 \\
\hline 2）化籸品の安定化 & メントール\}熔凮 \\
\hline 3）安 定 化 & 歯みがき \\
\hline \multicolumn{2}{|l|}{ 医薬品 } \\
\hline 1) 溶解度增大 & $\begin{array}{l}\text { プロスタグランジン, クロロマイ } \\
\text { セチン }\end{array}$ \\
\hline 2）味のマスキング & プロスタグランジン \\
\hline 3）粉末化(不揮発性) & $\begin{array}{l}\text { 二トログリセリン, ベンズアルデ } \\
\text { 七ド }\end{array}$ \\
\hline $\begin{array}{l}\text { 4) 安定化 (UV, 熱) } \\
\text { 擃 莯 }\end{array}$ & プロスタグランジン, ビタミン \\
\hline 1) 安定化(UV, 熱) & ピレスリン, ピレスロイド \\
\hline 2）粉 末 化 & DDVP など \\
\hline \multicolumn{2}{|c|}{$\begin{array}{l}\text { プラスティック } \\
\text { 色素,フレーバの安定化 色，臭 }\end{array}$} \\
\hline $\begin{array}{l}\text { 色素, フレーバの安定化 } \\
\text { そ の 他 }\end{array}$ & $\begin{array}{l}\text { 色, 臭 } \\
\text { 糊 }\end{array}$ \\
\hline
\end{tabular}

b ) 香料，スパイスなどをとり込ませて安定化させ る.

c ）悪臭物質を無臭化させ，加工，取り扱いを容易 にする.

d）医薬品，食品などの脱臭にも用いられる.

2）酸化，光分解などに対する分解性質を包接するこ とによって保護, 安定化させる。

a ) 紫外，可視光線などに弱い化合物，たとえば農 薬，食用色素なぞを包接して安定化させる(図 4).

b）酸化されやすいるの，分解されやすい過酸化物 などを安定化させる場合がある（図 5，表 8 ）。

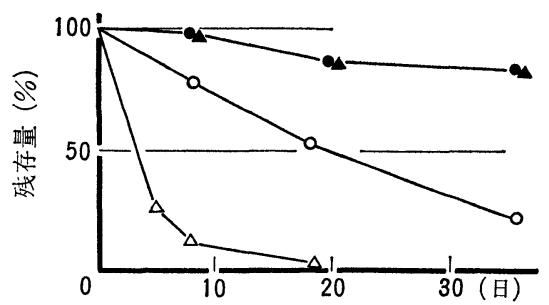

図 4 アレスリンと $\beta$-CD 包接化合物の分解 ${ }^{(21)}$

: : アレスリンの $\beta-C D$ 包接化合物とウェッタブルパウ ダの混合物

A : アレスリンの $\beta-\mathrm{CD}$ 包接化合物とタルクの混合物

○:アレスリンとデキストリン，ウエッタブルパウダの 混合物

$\triangle$ : アレスリンとデキストリン,タルクの混合物

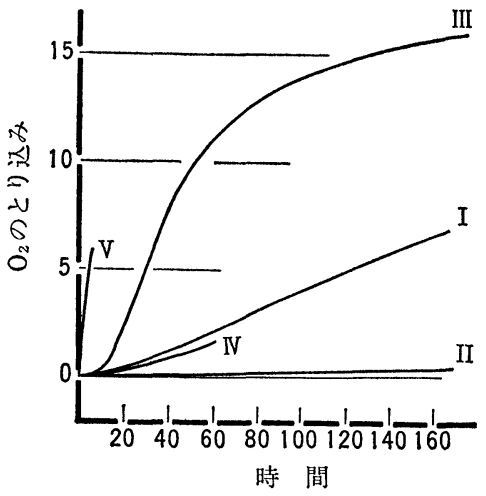

図:5 リノール酸, シンナムアルデヒドの安定化 ${ }^{(20)}$

I : リノール酸 $110 \mathrm{mg}$ と CD $1.5 \mathrm{~g}$

II : リノール酸 $117 \mathrm{mg}$ と CD $1.7 \mathrm{~g}$

III : リノール酸 $90 \mathrm{mg}$ のみ

IV : シンナムアルデヒド $105 \mathrm{mg}$ と CD $1 \mathrm{~g}$

$\mathrm{V}$ : シンナムアルデヒド $120 \mathrm{mg}$ のみ

表 8 プロスタグランジン $\mathbf{E}_{2}$ の安定化 ${ }^{(20)}$

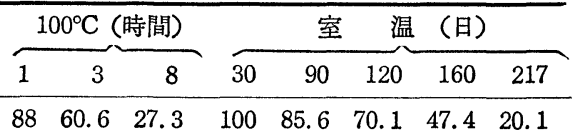

\begin{tabular}{lllllllll}
\hline $\mathrm{PGE}_{2}$ の & 88 & 60.6 & 27.3 & 100 & 85.6 & 70.1 & 47.4 & 20.1
\end{tabular} み

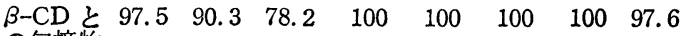
の包接物

注）数字は0 時の活性に対する一定の時刻の残存活性を\%で 表わしたもの.

3）包接されるゲスト化合物の物理的，化学的性質を 変化させる。

a）水に不溶な医薬品などの疎水基を $\mathrm{CD}$ の環の中 にとり込ませて溶解度を增大させる場合がある.

b）色素のマスキングまたは色調シフトによる商品 のイメージ変化.

c）食品または医薬品などの苦味のマスキング.

d）潮解性物質を包接することによって安定化させ る.

e ）混和することによって反応を起こしやすい物質 の反応を防止して混合を可能にする.

f ）一部の官能基を保護し，選択反応を可能にする.

$\mathrm{g}$ ）ある種の物質の分解を促進させる場合もある.

4）界面活性剂としての作用がある.

a ）ステロイド，炭化水素，油などを分散させる.

b）水畜産練製品，マヨネーズ，ドレッシングなど 合成界面活性剂と同様に用いることができる。

5）種々の物質の粉末化基材として用いられる.

6）その他 

a) 糊としての利用.
b）プラスチック製品への利用.

*

$\beta-\mathrm{CD}$ の工場スケールでの生産に焦点をあてつつ, $\beta-$ $\mathrm{CD}$ および CD 含有の混合物についてその用途を述べた. CD そのものは 1891年に発見されているにもかかわらず, 長い間その用途についての研究は行なわれないできた. この原因についてはすでに述べたが，好アルカリ性 $B a-$ cillus を用いたアルカリ性醊酵法によってこの問題は全 部解決された. そして, 食品衛生法上まったく問題のな い結晶 $\beta-\mathrm{CD}$, 直鎖のデキストリンを含む $\alpha, \beta, \gamma-\mathrm{CD}$ の 混合物が安価に市販されるようになった現在, その用途 は急激に開けつつある. 原料的には太陽エネルギーを利 用して作られた洪粉であり，しかも生物によって炭酸ガ スと水になってしまう安全な化合物である. 今後の開発 研究によって，さらにニニークな用途が開けてくるもの と思われる。

近代微生物学はパスッール以来ほぼ 100 年しかたって いない若い学問であり，まだまだ知のものは多い，恩 師坂口䔆一郎先生がいつるいって括られたよらに, 基礎 も応用もない学問である. 応用から基礎が，また基礎か ら応用がでてくるものである. 新しい考えをだしたとき には新しい微生物が発見され, 新しい学問, そして応用 の分野が開ける，といっても過言ではない.

好アルカリ性微生物については誌面の都合であまり説 明しなかったが, 興味のある読者はいくつかの総説(24 26) を参照されたい，また，CD についても多くの優れた総 説 ${ }^{(3,7,14)}$ があり, 特に用途面については御船らの労作が ある(7).なお，これら総説より資料の一部を引用させて いただいたことを心から感謝する次第である.

\section{文 献}

1) A. Viller : Compt. rend., 112, 435(1891).

2) F. Schardinger : Z. Untersuch. Nahr. Genussm., 3, 865(1903).

3) D. French : Adv. Carbohydr. Chem., 12, 189(1957).

4) A. O. Pulley \& D. French : Biochem. Biophys. Res. Commun., 5, 11(1961).

5) D. French et al.: Arch. Biochem. Biophys., 111, 153 (1965).

6) Corn Products Co. : " $\beta$-Cyclodextrin", Catalogue, 1968.

7) 御船 昭,島 淳之: 有機合成化学協会誌, 35, 116(1977).

8) K. Horikoshi : Agric. Biol. Chem., 35, 1407 (1971).
9) N. Nakamura \& K. Horikoshi : ibid., 40, 753(1976).

10) N. Nakamura \& K. Horikoshi : ibid., 40, 935(1976).

11) N. Nakamura \& K. Horikoshi : ibid., 40, 1647(1976).

12) N. Nakamura \& K. Horikoshi : ibid., 40, 1785(1976).

13) M. Matsuzawa et al.: Die Stärke, 27, 410(1975).

14）小林昭二, 貝沼圭二 : 醴酵と工業, 36, 176(1978).

15）日本食品化工株式会社 カタログ “Celdex”, 1978.

16) J. Thoma et al.: "Starch ; Chemistry and Technology" Vol. 1, Academic Press N.Y., 1965, p. 209.

17) D. French et al. : Die Stärke, 8, 280(1963).

18) G.H. Anderson et al. : Toxicol. Appl. Pharmacol., 5, 256(1963).

19) F. Cramer \& F. M. Heuglein : Chem. Ber., 90, 2561 (1957).

20) 日本特許 No. $50-3362$.

21) I. Yamamoto et al. : J. Pesticide. Sci., 1, 41(1976).

22）米田豊秋: 食品之科学, 19, 97(1977).

23) H. Schlenk et al.:J. Amer. Chem. Soc., 77, 3587 (1955).

24）掘越弘毅：化学と生物, 11, 406(1973).

25) 掘越弘毅 : 現代化学, No. 96, p. 24(1979).

26）掘越弘毅：サイエソス, Vol 9, No. 3, p. 112(1979).

\section{シクロデキストリンの化学}

ベンダー・コミヤマ 著

平井英史 - 小宮山真 訳

A5判 $/ 180$ 頁 $/ 2700$ 円

シクロデキストリンは，グルコースが 6 ～9 個縮合す ることにより形成される円筒状の環状多糖である. 特 徵として包接化合物の形成, 触蝶作用などにおける基 質特異性があげられ，また近年は医薬品への応用など に多大の注目を集めている。本書では，シクロデキス トリンの構造物性から触媒作用, さらには実用面への 応用までを平易に述べる。

$\begin{array}{ll}1 & \text { 緒 } \\ 2 & \text { 構造と性質 } \\ 3 & \text { 包接化合物の形成 }\end{array}$

4 触媒作用と実用的応用

5 共有結合的触媒作用

6 非共有結合的触媒作用

7 不斉触媒作用

8 共有結合的および非共有結合的修飾による改良

9 結 語

文献／著者索引／事項索引 